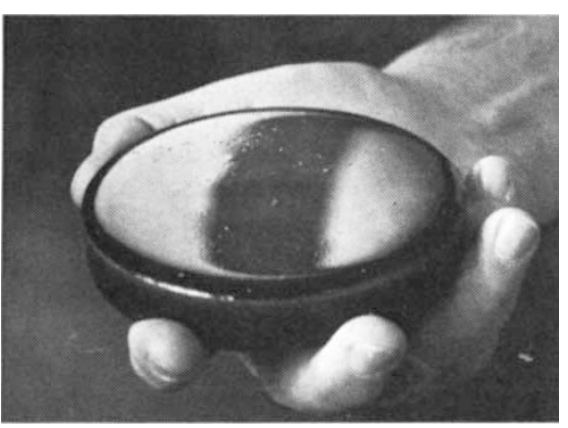

Product of Harvest

Harwell's Harvest; its successor AVM, incorporated in a plant at Marcoule which began operation two years ago, is continuous, allowing - it is claimed - a roughly twofold saving in capital equipment costs for the same waste throughput. The AVM plant is remotely controlled, and is constructed from units none larger than $500 \mathrm{~kg}$ for ease of handling and replacement. The French process is thus many years ahead of its British - or any - rival.

Nevertheless there is still a question mark over BNFL's haste to conclude an agreement with Cogema. The decision to abandon Harvest is as much a political as a commercial one. At present, about $1,000 \mathrm{~m}^{3}$ of high active waste is stored in liquid form in tanks at Windscale, and BNFL still considers that it could remain in these tanks, or new ones, for some decades. Further tanks could be built for the oncoming nuclear power programme, but it is felt that public opposition to the programme - which will be expressed in the promised PWR enquiry - may be less if vitrification work is seen to be progressing apace. The argument, however, turns a

\section{The differences}

High active waste emerges as a liquid from the reprocessing of spent fuel: it is a solution in concentrated nitric acid of the nitrates of actinides and fission products. The object of vitrification is to immobilize the radioactive elements. In the Harvest processs, which is only at the pilot stage, a simulated waste is mixed with the components of a borosilicate glass, poured into a tube, evaporated and glassified in one step in a furnace. The tube becomes the primary container for the glass. The process is a batch process. In the AVM technique, a high active liquid stream is evaporated and calcined (converted to oxides) in a rotary calciner. Each hour, the calciner accepts 40 litres of liquid waste and converts it to brown granules, which leave the furnace continuously. The granules are mixed with borosilicates and melted in a stainless steel container. Every eight hours, the container pours out $140 \mathrm{~kg}$ of glassified waste into storage drums. The drums are moved out, lids are welded on, and the drums moved to storage caves all automatically. blind eye to local opposition to drilling tests, to find sites for future long-term disposal of the glass.

At Harwell, Dr Ron Flowers, who heads the chemical technology division that developed Harvest, says that he expects to close work on the project by next March, once experiments are completed and final publications prepared. Loss of the Harvest contract - which was paid for by BNFL, the Central Electricity Generating Board, and the Department of the Environment will not be a serious blow to the division, he says.

Robert Walgate

\section{Soviet dissidents Another taken}

Viktor Brailovskii, the Moscow Jewish mathematician who regularly hosts the Sunday seminars for refusnik scientists, was arrested last week, reportedly under Article 109/1 of the Criminal Code which deals with slander of the Soviet Union and the socialist system and the circulation of "publications known to be false".

News of the arrest, coming shortly after the opening of the Madrid review conference on implementation of the Helsinki Final Act, has caused consternation among his colleagues and friends abroad, who see it not only as a threat to Brailovskii himself, but also an adverse omen for Soviet intentions regarding "Basket 3" of the Final Act, which deals with human rights.

Brailovskii, who is a specialist in cybernetics and computer programming, first applied to emigrate to Israel in 1972. His application was refused, and he was then dismissed from his academic post. Since then, he has had no chance of obtaining any job in science.

It was to help such "refusnik" scientists keep up their academic interests that the Sunday seminars were founded in 1973 by Aleksandr Voronel'. When Voronel' and then his successor as seminar leader Mark Azbel' finally managed to emigrate, Brailovskii and his wife Irina (also a mathematician) became hosts to the seminar.

A recent Western visitor reports that in spite of a total lack of access to scientific facilities, including journals, the standard of discussion remains high, and there is considerable participation by young Jewish scientists who are attempting to carry out some kind of postgraduate study on their own.

A frequent visitor to the seminar, the traveller said, is Evgenii Chudnovskii of Khar'kov - a city where the refusal rate has always been particularly high - who is now trying to organize what he calls a "Jewish university" for young refusniks

According to Mrs Brailovskaya, the seminars will continue in spite of her husband's arrest. The citation of Article $109 / 1$ presumably refers to the samizdat journal Jews in the USSR, of which
Brailovskii was for a time editor. However, this journal ceased publication in summer 1979, and the long delay before an accusation on this charge seems unreasonable.

\section{German science \\ New man arrives}

Germany has a new Minister for Science and Technology: 43-year-old Andreas von Bülow, who since 1976 has been Parliamentary Undersecretary of State for Defence. The Bundesministerium für Forschung und Technologie BMFT is Dr von Bülow's first ministerial appointment - as it was for his predecessor, Dr Volker Hauff. Dr Hauff now moves on to the Ministry of Transport, which is considered to be a more senior political appointment.

Dr von Bülow has had no time yet to form his policies for the BMFT, but he is expected to lean more to the right of his party, the SPD, than Dr Hauff, who attempted to use the ministry as an

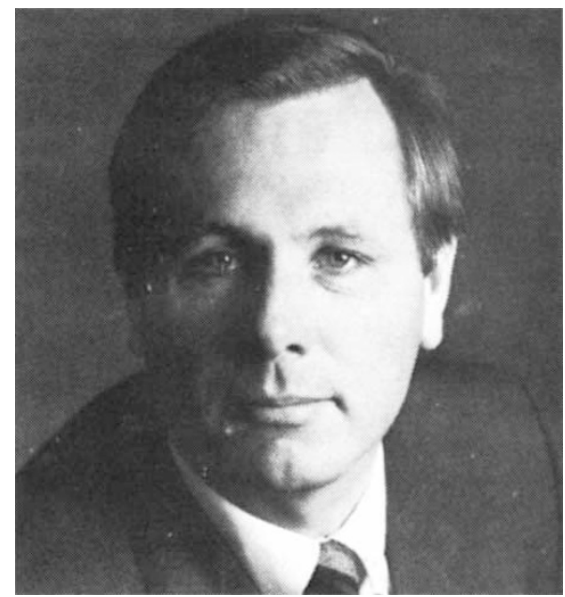

instrument of economic policy (through its involvement in technology). But Dr Hauff - after seven years in some capacity at the BMFT - was said to be becoming impatient at the inertia of the research community, and particularly the big science institutions like the Karlsruhe nuclear research centre and others which had grouped themselves into a powerful lobby, the Arbeitsgemeinschaft der Grossforschungseinrichtungen (AGF). It remains to be seen what $\mathrm{Dr}$ von Bülow will do with that. His ministry plays a coordinating role in German science, akin to that of the Delegation Générale à Recherche Scientifique et Technique in France; but it controls a much larger budget - around DM 6 billion ( $£ 1.25$ billion). This is the bulk of the federal finance applied to R\&D Germany, another DM 3 billion or so being under the direct control of other ministries. (A further DM 6 billion is spent by the state governments, mostly to support universities, and DM 16 billion by industry.) The BMFT, along with the state governments, supports the institutions of the AGF, the Max Planck Gessellschaft (which runs the Max Planck institutes), the Deutsches 